University of Warwick institutional repository: http://go.warwick.ac.uk/wrap This paper is made available online in accordance with publisher policies. Please scroll down to view the document itself. Please refer to the repository record for this item and our policy information available from the repository home page for further information.

To see the final version of this paper please visit the publisher's website. Access to the published version may require a subscription.

Author(s): Nicola Pratt

Article Title: The Queen Boat case in Egypt: sexuality, national security and state sovereignty

Year of publication: 2007

Link to published version: http://dx.doi.org/

10.1017/S0260210507007346

Publisher statement: None 


\title{
The Queen Boat case in Egypt: sexuality, national security and state sovereignty
}

\author{
NICOLA PRATT*
}

\section{Introduction}

Why? Why is it bothering them so much? Why do they have to torture us? Why do they care? We don't do anything to anyone else. Who do we harm? Why do they hate us? Why?

'Naguib', interviewed in 2003 regarding his experience of being arrested for being gay in the provincial Egyptian city of Tanta. ${ }^{1}$

The government's targeting of homosexuality in M ay 2001, following years of 'turning a blind eye' to Cairo's gay scene, ${ }^{2}$ is studied here in terms of the links between the sphere of interpersonal relations and notions of national security within international relations. The persecution of men for alleged same-sex relations not only filled newspaper columns and created a spectacle to divert people's attention away from the government's failings. ${ }^{3} \mathrm{M}$ ore importantly, the event represented an opportunity for government officials, the media and other civil society activists both within E gypt and abroad - to 'perform' a discourse of national security through which national sovereignty was (re)produced and political order was maintained. ${ }^{4}$ However, this national security threat was not only posed by the external threat of W estern governments, international N G Os and other transnational actors concerned with respect for human rights within Egypt. More importantly, this threat was constructed as originating with those people failing to conform to the 'norm' of heterosexual relationships.

By focusing on a particular case study, this article builds upon the work of feminist IR theorists in revealing the way in which gender both constitutes and is constituted by international politics and security in a continual process. Security is of interest to feminist IR theorists because those events and processes traditionally at the heart of

* Earlier forms of this article were presented to colleagues at the School of Political, Social \& International Studies, UEA, in N ovember 2004 and participants in the 'H egemonic M asculinities in International Politics' conference at the U niversity of $\mathrm{M}$ anchester, $\mathrm{M}$ ay 2005 . The author thanks all those who commented on this paper in these fora, in addition to the very constructive feedback from the anonymous reviewers. I hope this final version will do justice to their valuable input.

1 Scott L ong, 'The Trials of Culture: Sex and Security in Egypt', Middle East Report Online, no. 230, 〈http://www.merip.org/mer/mer230/230_long.html〉, accessed 18 J une 2004.

2 H ossam Bahgat, 'Explaining Egypt's Targeting of Gays', Middle East Report and Information Project Press Information Note, no. 64, 23 J uly 2001, 〈http//www.merip.org/mero/mero072301.html〉, accessed 18 J une 2004; Sarah K ershaw, 'Cairo cracks down on the gay scene', New York Times, 23 A pril 2003; H uman Rights W atch (HR W), In a Time of Torture: The Assault on Justice in Egypt's Crackdown on Homosexual Conduct (N ew Y ork: H R W, 2004), p. 16.

3 Bahgat, 'Explaining Egypt's Targeting of Gays'.

4 F or an elaboration of the concept of security as a discourse for performing national identity, see D avid Campbell, Writing Security: United States Foreign Policy and the Politics of Identity (M anchester: M anchester U niversity Press, 1992). 
security studies, such as war and militarism, tend to affect women negatively and differently from men - for example, in the creation of large numbers of refugees and the use of rape as a weapon of war. ${ }^{5}$ M oreover, the discourse and practices of national security are rooted in (gendered) assumptions of 'masculinized dignity and feminized sacrifice that sustain that sense of autonomous nationhood'. ${ }^{6}$ The concept of 'human security' expands the security agenda to not only include the gendered implications of state security but also 'the safety of the body and the household'. ${ }^{7}$ In this sense, national security in international relations is not only 'about arms dealers, presidents' men and concepts such as "covert operations" ', 8 but also about 'ordinary' women and men trying to secure their own livelihoods and lifestyles in the context of evolving socioeconomic conditions and political processes.

The Queen Boat case illustrates how 'The body as the finest scale of geopolitical space is critical to a feminist understanding of [. . .] human security. ${ }^{9} \mathrm{H}$ owever, it is not only by locating women's bodies that we are able to understand the gendered dimensions and implications of the international system. A focus on men and their relationships also reveals the ways in which national sovereignty and security are constituted through notions of gender identities and relations and vice versa. M oreover, the study of the Egyptian government's persecution of gay men illustrates that international relations are not only gendered but also sexualised. Sexual relations and identities are not only a private/intimate matter but also 'an arena of constant surveillance and control'10 and an inextricable part of the national and state processes that constitute the sphere of international politics. ${ }^{11}$

This article explores the Q ueen Boat case in five sections, which address the themes highlighted in the previous paragraphs. The first section identifies the ways in which the Queen Boat case may be seen, in the first instance, as official punishment of homosexuality in order to reproduce heteronormativity. Following this, I argue that the reproduction of heteronormativity is significant within a context in which individuals are experiencing shifting gender roles as a result of economic insecurities and government attempts to promote women's position. The next section illustrates how the case was constructed as a matter of national security. In this way, the final sections demonstrate how the case became an opportunity for the construction of national identity and, based upon this, the 'performance' of national sovereignty, in opposition to the W est. The conclusion brings together these findings to explore the implications of the Q ueen Boat case for thinking about the gendered and sexualised nature of international relations.

5 A nn Tickner, Gender in International Relations: Feminist Perspectives on Achieving Global Security (N ew Y ork: Columbia U niversity Press, 1992); W enona G iles and J ennifer H yndmann (eds.), Sites of Violence: Gender and Conflict Zones (Berkeley, CA : U niversity of California Press, 2004).

${ }^{6}$ Cynthia Enloe, Bananas, Beaches and Bases: Making Feminist Sense of International Politics (London: Pandora, 2000), p. 197.

7 Wenona Giles and J ennifer H yndmann, 'N ew Directions for F eminist R esearch and Politics', in Giles and H yndmann, Sites of Violence, p. 308.

8 Enloe, Bananas, p. 11.

9 Giles and Hyndmann, 'N ew Directions', p. 310.

10 Dennis A Itman, Global Sex (Chicago, IL: U niversity of Chicago Press, 2001), p. 2.

11 V. Spike Peterson, 'Sexing Political Identities: N ationalism as H eterosexism', in Sita R anchod-N ilsson and M ary A nn T étreault (eds.), Women, States and Nationalism (L ondon: R outledge, 2000), p. 59. 


\section{The international politics of targeting homosexuality in E gypt}

\section{Punishing homosexuality}

In the early hours of 11 M ay 2001, several hundred police descended upon the ' $Q$ ueen Boat', a tourist boat moored on the Nile in Cairo and the location of a disco informally known to be a hang-out for gay men.12 That night, some 60 men were arrested and detained at different police stations around Cairo. F ifty-four were transferred to prison and 52 were later charged with 'debauchery' or fujur (homosexuality is not actually an offence on the E gyptian statute books). ${ }^{13}$ The arrests came within a context of increased state surveillance of Egyptian gay men interacting through websites and chat-rooms. A significant number of gay men were and continue to be arrested through entrapment by police via gay chat-rooms, in addition to being identified by informants. ${ }^{14}$

U ntil a few months previous to the Queen Boat arrests, the Egyptian authorities had generally turned a blind eye to the activities of the gay community in Egypt and some observers even considered Egypt's gay community and nightlife to be thriving. ${ }^{15} \mathrm{~A}$ number of pubs and parties emerged in the 1990s giving greater space and relative safety for gay men to meet.16 That is not to say that homosexuality was beginning to become socially acceptable but to draw attention to the fact that the Queen Boat case did not represent the 'natural' continuation of the persecution of gay men in Egypt. ${ }^{17}$

The Q ueen Boat case and subsequent prosecutions clearly represent a violation of basic human rights to security of the person. A common theme in the arrests of allegedly gay men in Egypt is their subject to torture and other humiliating practices at the hands of the police. ${ }^{18}$ Several human rights reports detail the incidence of torture during the detention and questioning of men accused of being gay. These include the use of torture techniques and other forms of ill-treatment within Egyptian police stations that are common to other arrests, such as being beaten by a stick on the soles of the feet (falaka), beaten with fists, slapped with the flat of the hand and

12 In addition, several more men were arrested in other locations in Cairo that night, including in people's homes. A mnesty International (AI), 'T orture and Imprisonment for A ctual or Perceived Sexual Orientation', Press R elease, 20 D ecember 2001, 〈http://web.amnesty.org/library/print/ EN G M DE 120332001〉, accessed 26 October 2004.

13 Ibid.; HRW, In a Time of Torture, p. 13. The law used to prosecute the Queen Boat defendants originated within the context of anti-colonial struggles against British 'immorality'. In 1951, Egyptian nationalists proposed a law to abolish state-licensed brothels established to service the 'needs' of the British military. Fujur was originally conceptualised within this legislation as referring to prostitution.

14 Bahgat, 'Explaining Egypt's Targeting of Gays'; International Secretariat of OM CT (W orld Organisation A gainst Torture), 'A rbitrary A rrest, D etention and Torture of Suspected "'G ays"' ', Press R elease, $8 \mathrm{M}$ arch 2002, posted to 〈http://www.gayegypt.com/wororagtor8m.html〉, accessed 26 O ctober 2004; G ayE gypt.com, 'A Brief H istory of Egypt's G ay W itch H unt: M ay 2001-F ebruary 2003', 〈http://www.gayegypt.com〉, accessed 26 October 2004; HR W, In a Time of Torture.

15 Bahgat, 'Explaining Egypt's Targeting of G ays'; K ershaw, 'Cairo cracks down on the gay scene'.

16 H RW, In a Time of Torture, p. 16.

17 In one newspaper interview, 'M ichael', an Egyptian gay man says, 'Even if the government accepts [homosexuality] and makes it official, the people will still refuse it . . . They think that being gay is shameful and brings Egypt a bad reputation'. Cited in Lilian Lang, 'Hiding themselves in the crowd', Middle East Times, issue 33, 1999, hosted at: 〈http://www.gayegypt.com/newrepongayi.html〉, accessed 28 A pril 2006.

18 AI, 'Torture and Imprisonment'; OM CT, 'A rbitrary A rrest, D etention and Torture of Suspected "Gays" '; HRW, In a Time of Torture. 
whipped across the back with a hose. ${ }^{19}$ A s one of the accused in the Q ueen Boat case told A mnesty International:

The real beatings started in the police station. They beat us with their hands and legs and with a cane and a thick stick. ${ }^{20}$

Other incidences of ill-treatment and torture appear to be specific to the detention of men accused of engaging in homosexual acts. F or example, detainees are forced to undergo examinations by forensic experts for evidence of anal sex.21 They are made to strip to show their underwear and to confess, under duress, whether they are active or passive. ${ }^{22}$ In prison, the defendants are beaten not only by prison staff, but also by other inmates, with the encouragement of staff, because they are gay. ${ }^{23}$ They are subject to verbal abuse by police and prison officers, such as, being called khawal (pl. khalwalat) - a derogatory term for gay.

It was not only the defendants in the Queen Boat case that were subject to humiliation and ill-treatment by the state. In addition, the men's families were subject to harassment and humiliation, not only by the state but also by the national media. U nusually, in the Q ueen Boat case, the press were allowed to take photographs of the men in detention.24 The names and workplace addresses of the accused were published by a semi-official national newspaper, thereby potentially subjecting the men and their families to harassment. ${ }^{25} \mathrm{M}$ oreover, their families were also subject to verbal abuse and stigmatisation. For example, during the trial, the court guards would jeer at the defendants' mothers, 'Y ou are the ones who spawned the khawalat!', 26

The 'Queen Boat' trial began on 18 July 2001. On 14 November 2001, of the original 52 prisoners, 21 were found guilty of 'habitual debauchery' and sentenced to terms of one to two years. The key defendant was given a five-year sentence for 'contempt of religion' and debauchery and his alleged aide received a three-year prison sentence for 'contempt of religion'.27 The remaining 29 defendants were acquitted. 28

In late M ay 2002, the Egyptian president, Hosni M ubarak, used his powers to rescind the verdicts of the trial except for those of the alleged ringleaders who had both been convicted of 'contempt of religion'. A Il the defendants' files, including the

19 A I, 'T orture and Imprisonment'; H R W, In a Time of Torture, p. $32 \mathrm{ff}$. The systematic use of torture by Egyptian police officers over the last decade has been extensively documented by Egyptian and international human rights groups. For example, A mnesty International (AI), 'E gypt: Time to Implement the UN Committee against Torture R ecommendations', A I Index: M DE 12/038/2003, 20 N ovember 2003, 〈http://web.amnesty.org/library/print/E N G M DE 120382003〉, accessed 12 M ay 2005.

$20 \mathrm{Al}$, 'Torture and Imprisonment'.

21 Ibid.

22 HRW, In a Time of Torture, pp. $32 \mathrm{ff}$.

$23 \mathrm{Al}$, 'Torture and Imprisonment.

24 Ibid.

25 Al-Ahram and Al-Gumhuriyya (both state-owned newspapers) published the full names, ages, professions and workplaces of the 52 defendants on 29 J une 2001, even though this is illegal according to Egyptian law. Cited in, HRW, In a Time of Torture, fn. 126.

26 HRW, In a Time of Torture, pp. $32 \mathrm{ff}$.

27 The key defendant was charged with establishing a religious group called 'G od's A gency on Earth'. The charge of 'contempt of religion' was used to justify the trial of the men in a state security court. Under Egyptian law, 'contempt of religion' is punishable by between six months and five years imprisonment. A ge of Consent, " "Immorality" Trial R econvenes in Egypt', 29 A ugust 2001, 〈http://www.ageofconsent.com/egypt.htm〉, accessed 6 D ecember 2004.

${ }^{28} \mathrm{G}$ ayE gypt.com, 'A Brief H istory of Egypt's G ay W itch H unt'; A I, 'Torture and Imprisonment'. 
21 who were acquitted, were referred to the state prosecution service for review and those who had been found guilty were released on bail. ${ }^{29}$ O ne month later, the state prosecution referred all the original defendants to be retried in a Cairo criminal court.

In M arch 2003 (almost two years after the original arrests took place), the court again found 21 of the defendants guilty of 'habitual debauchery'. This time they were sentenced to a harsher sentence of three years in prison followed by three years of police probation. The case was appealed in a higher court on J une 4 and the sentences of 14 of those convicted for debauchery were reduced to time served and a year's probation (meaning that they would have to sleep in police cells every night possibly facing the same police brutality that they experienced whilst detained/ imprisoned). ${ }^{30}$ Since the high profile 'Q ueen Boat case', scores of Egyptian men have been arrested and prosecuted for 'habitual debauchery'. ${ }^{31}$

In light of the fact that homosexuality is not explicitly prohibited by E gyptian law, the defendants in the Queen Boat case and other subsequent cases have been prosecuted according to a law criminalising prostitution (or 'debauchery'). Y et, despite the fact that consensual homosexual sex is not explicitly criminalised, the case brought against the men depended upon proving that they had engaged in (consensual) same-sex relations. A ccording to the judge at the first Queen Boat trial, the evidence relied upon to reach the guilty verdicts were: (1) confessions; (2) photographs in some of which several of the defendants appeared naked and/or engaged in same-sex acts; and (3) forensic medical examinations. 'These combined pieces of evidence were the ones that made the court absolutely sure of the convictions'. ${ }^{32}$ H owever, the evidence for the convictions 'rarely amounted to such "certainty" and the combinations of evidence [] udge] A bdel K arim cited were almost nonexistent'. 33

The trial and harassment of men on the basis of their sexual orientation represents a violation of the principle of non-discrimination in the enjoyment of human rights. ${ }^{34}$ H owever, the persecution of individuals because of their sexual orientation should be seen not only as an infringement of basic rights to the security of the individuals involved but as part of general attempts by state and society to control the sexuality of men and women. $U$ sually, this control is more notable for women because of its frequent discriminatory and violent implications. F or example, Egyptian legislation does not grant women and men equal access to divorce. Women's right to pass on their nationality to their children is also restricted (thereby penalising the children of women who marry non-Egyptians). 35 The increased occurrence of 'veiling' amongst Egyptian women since the 1970s, and the continued prevalence of F emale Genital

29 Jailan H alawi, 'Queen Boat Case Overturned', Al-Ahram Weekly On-line, 30 M ay-5 J une 2002, 〈http://weekly.ahram.org.eg/2002/588/eg2.htm〉, accessed 26 October 2004.

30 Jailan H alawi, 'Convicted Before the F act', Al-Ahram Weekly Online, 20-27 M arch 2003, 〈http://weekly.ahram.org.eg/print/2003/630/eg9.htm〉, accessed 26 October 2004; A I-F atiha, 'Statistics on G ay A rrests in Egypt', 26 September 2003, 〈http://www.sodomylaws.org/world/egypt/ egnews160.htm〉, accessed 26 October 2004.

31 It is suggested that many more cases of harassment and prosecution of gay men in Egypt take place than is reported. This is due to the fact that, since the 'Queen Boat' trial, the Egyptian government has clamped down on media reporting of arrests of gay men due to mounting international criticism. See A I-F atiha, 'Statistics on G ay A rrests in Egypt'; H R W, In a Time of Torture.

32 Interview with J udge M uhammed A bdel K arim, Cairo, Egypt, 11 M arch 2003, cit. in H R W, In a Time of Torture, p. 44.

33 Ibid.

$34 \mathrm{Al}$, 'Torture and Imprisonment'.

35 A mira El-A zhary Sonbol, 'Egypt', in Sameena N azir (ed.), Obstacles and Opportunities towards Women's Rights in the Middle East and North Africa (N ew Y ork: F reedom H ouse, 2005), pp. 69-86. 
Cutting may also be interpreted as social attempts to control women's sexuality - a trend in which women, themselves, are also complicit. 36

Violence against women (in different forms) operates to punish transgressions of social norms about women's sexual behaviour. Domestic violence is justified as a means of punishing wives who disobey their husbands or who fail to live up to gender role expectations. ${ }^{37} \mathrm{M}$ en sometimes resort to killing their female relatives (usually daughters or sisters) 'for engaging in, or being suspected of engaging in, sexual practices before or outside marriage', ${ }^{38}$ Such 'honour' crimes often receive a mitigated sentence in Egypt. ${ }^{39} \mathrm{As}$ women are punished for failing to conform to dominant notions of female sexual behaviour, so gay men, in the Queen Boat case and subsequent prosecutions, are punished for failing to conform to dominant notions of male sexual behaviour.

$Y$ et, the Q ueen B oat case also marked a break from the past because it was the first time gay men had been put on trial and, thereby, represented a public acknowledgement that homosexuality existed in Egypt. ${ }^{40}$ This enabled a public discussion of homosexuality that could be seen to serve certain specific interests. ${ }^{41}$ One commentator has argued that the specific interests served by the Queen Boat case were those of the Egyptian government. The very public clampdown on the gay community acted to create a public spectacle to divert attention from Egypt's ongoing economic recession, as well as enabling the regime to assert its 'Islamic' credentials in the face of the relative success of the $\mathrm{M}$ uslim Brotherhood in the N ovember 2000 parliamentary elections and the Bar A ssociation elections in early 2001.42 W hilst government insecurity no doubt played a role in the authorities' decision to publicly persecute homosexuality, this article illustrates the ways in which the case was not merely a matter of deflecting attention away from the regime's difficulties. Statements by politicians and civil society actors, as well as media commentary, converged to present the case as serving wider, national interests. M oreover, the case sought to restructure a variety of power relations at the interpersonal, national and international levels.

\section{State insecurity and sexual/gender insecurities}

The targeting of gay men should be partly understood as a government response not only to its own vulnerability but also to the economic and geopolitical insecurity of

36 A rlene M acleod, Accommodating Protest: Working Women, the New Veiling, and Changes in Cairo (N ew Y ork: Columbia U niversity Press, 1991); N adia W assef and A bdullah M ansour, Investigating Masculinities and Female Genital Mutilation in Egypt (Cairo: the N ational N G O Centre for Population and D evelopment, 1999).

37 M arlyn Tadros, Rightless Women, Heartless Men: Egyptian Women and Domestic Violence (Cairo: L egal R esearch and R esource Centre, 1998).

38 Lama A bu Odeh, 'C rimes of H onour and the Construct of $G$ ender in A rab Societies', in M ai Y amani (ed.), Feminism and Islam (R eading: I thaca, 1996), p. 141.

39 Centre for Egyptian W omen's L egal A ssistance, " "Crimes of H onour" as Violence against W omen in Egypt', in L ynn W elchman and Sara Hossain (eds.), 'Honour': Crimes, Paradigms and Violence against Women (London: Zed Books, 2005), pp. 144-5.

40 L ong, 'The Trials of Culture'.

41 Lee Edelman, 'Tearooms and Sympathy, or, The Epistemology of the Water Closet', in A ndrew Parker et al. (eds.), Nationalisms and Sexualities (L ondon: R outledge, 1992), p. 268.

42 Bahgat, 'Explaining Egypt's Targeting of G ays'. 
the state and, related to this, the socioeconomic insecurities experienced by Egyptian men. As a result of an ongoing economic crisis throughout the 1980s, Egypt was obliged, in 1991, to adopt neoliberal economic reforms as a means of accessing grants and loans from the international community to fund national development. This programme, agreed with the IM F and World Bank, led to a gradual dismantling of the state-dominated economy, including the privatisation of public sector enterprises, restructuring of the public sector workforce and the liberalisation of the capital markets. Simultaneously, an agricultural modernisation programme and land reform programme occurred.

The economic reform programme also dismantled many of the social welfare mechanisms associated with the public sector - such as job security, job-related healthcare and pensions, rent ceilings and food subsidies. I n addition, the agricultural modernisation programme has led to the dispossession of peasants no longer able to afford increasing land rents. D espite the creation in 1991 of one of the largest social funds in the world, the rate of poverty in Egypt is perceived by some to have been growing. Between 1990/91 and 1997/98, the number of persons living on 2 dollars a day rose from 20.7 per cent to around 50 per cent.43 M oreover, in 2000, the government was obliged to devalue the currency by 30 per cent in an attempt to make its exports more competitive. As a result, Egyptians' purchasing power was greatly reduced, as the cost of imports rose. Additional sales taxes were also introduced in 2000 , despite private sector complaints of falling sales. ${ }^{44} \mathrm{U}$ nemployment continues to grow with half a million new entrants to the labour force every year. ${ }^{45} \mathrm{M}$ eanwhile, Egypt's health and education indicators continue to lag behind those of countries with similar levels of national income. ${ }^{46}$

The socioeconomic difficulties associated with economic liberalisation have been felt by all social groups, including public and private sector workers, peasants, university graduates, civil servants and even business people. The effects of economic liberalisation are not only felt by individuals or families in terms of loss of income, unemployment or reduced access to decent healthcare and education. They are also felt in terms of their impact upon gender roles, relations and identities. ${ }^{47}$ E conomic restructuring represents a challenge to prevailing gender norms, enshrined in legislation, whereby men are seen as the main providers and protectors of the family, whilst women are cast as mothers and wives, whose primary sphere of activity is the home. 48

${ }^{43}$ A mongst others, see $\mathrm{H}$ eba El-L aithy and M ohamed Osman, 'Profile and Trend of Poverty and Economic Growth in Egypt', R esearch Paper Series (Cairo: U nited N ations D evelopment Programme/l nstitute for N ational Planning, 1996); G aurav D att et al., 'A Profile of Poverty in Egypt: 1997', Food Consumption and N utrition Division D iscussion Paper no. 49 (Cairo: International Food Policy R esearch Institute, 1998).

44 A ziza Sami, 'This Y ear's H ot Potato', Al-Ahram Weekly Online, 3-9 J anuary 2002, 〈http://weekly.ahram.org.eg/2002/567/ec6.htm〉, accessed 19 M ay 2005.

45 Gihan Shahine, 'D ealing with the Dole', Al-Ahram Weekly Online, 3-9 M ay 2001, 〈http://weekly.ahram.org.eg/2001/532/fo1.htm〉, accessed 19 M ay 2005.

46 Egypt's H uman D evelopment Index ranking is amongst the lowest for a lower middle-income country. Human Development Report 2002 (N ew Y ork: U N D P, 2002).

$47 \mathrm{M}$ arianne $\mathrm{M}$ archand and A nne Sisson R unyan, 'Introduction - F eminist Sightings of G lobal R estructuring: Conceptualizations and R econceptualizations', in M archand and R unyan (eds.), Gender and Global Restructuring: Sightings, Sites and Resistances (L ondon: R outledge, 2000).

48 Iman Bibars, Victims and Heroines: Women, Welfare and the Egyptian State (London: Zed Books, 2001). 
Insecurities about gender identities generated by economic change may be expressed in a number of ways. One example is the prolific and very public debates surrounding the introduction of Viagra to Egypt in 1998.49 For several months, the national press was filled with articles about the drug, its benefits and its dangers. Calls for the legalisation of the drug were based on the notion that Egyptian men needed to prevent impotency and ensure their sexual performance in order to prove their masculinity. Similarly, in June 1996, various national newspapers and even members of the Egyptian parliament became involved in an investigation into the sale in E gypt of an Israeli chewing gum that was claimed to result in impotence for A rab men. 50

In other words, the theme of male anxieties about sexual performance is one that has recurred in contemporary Egyptian society. Some writers see these anxieties as rooted in the problems of securing one's daily existence - such as economic recession, inflation, poor education and high unemployment. ${ }^{51}$ I ndeed, research demonstrates that men feel emasculated by poverty. ${ }^{52}$

Others interpret male anxieties about their masculinity as a response to changing gender roles. ${ }^{53}$ In the post-independence period, gender roles have changed dramatically as part of the state-building process and a general expansion in the economy and the public sector. ${ }^{54} \mathrm{H}$ owever, whilst women's visibility in the public sphere became symbolic of national modernity, 55 until recently, women's rights within the home as defined by family law evolved very slowly. In 2000, the government successfully although with significant resistance-pushed through important reforms to family law by granting women the right to unilateral divorce - khula' - (albeit by relinquishing her financial rights within the marriage). ${ }^{56}$ In the same year, the $\mathrm{N}$ ational Council for Women was established, headed by the F irst L ady and reporting directly to the president, reflecting the high level of political commitment to raising women's status in Egypt. These measures aim to rectify the internationally poor record of Egyptian women's (formal) labour rate participation, illiteracy rates and other indicators of women's participation as a means of contributing towards improving Egypt's development. 57

49 W assef and M ansour, Investigating Masculinities, pp. $136 \mathrm{ff}$.

50 For a discussion of this 'moral panic', see M ai G houssoub, 'Chewing G um, Insatiable W omen and Foreign Enemies', in M ai G houssoub and Emma Sinclair-W ebb (eds.), Imagined Masculinities: Male Identity and Culture in the Modern Middle East (London: Saqi Books, 2000), pp. 227-35.

51 Wassef and M ansour, Investigating Masculinities, pp. $136 \mathrm{ff}$.

52 K amran A sdar A li, 'N otes on R ethinking M asculinities: A n Egyptian Case', in Sondra Zeidenstein and K irsten M oore (eds.), Learning About Sexuality: A Practical Beginning (N ew Y ork: Population Council/I nternational Women's H ealth Coalition, 1996), pp. 106-7.

53 G hossoub, 'Chewing Gum', p. 230.

54 F or example, see N adia H ijab, Womenpower (Cambridge: Cambridge U niversity Press, 1988).

55 Deniz K andiyoti, 'I dentity and its D iscontents: Women and the $\mathrm{N}$ ation', in Patrick W illiams and L aura Chrisnan (eds.), Colonial Discourse and Post-colonial Theory: A Reader (N ew Y ork: Columbia U niversity Press, 1994).

56 R eligious/social conservatives vehemently opposed these changes on the grounds that it would lead to the break-up of the family. F or example, see, M ariz Tadros, 'Who W on the Tug-of-W ar', Al-Ahram Weekly Online, 3-9 F ebruary 2000, 〈http://weekly.ahram.org.eg/2000/467/li1.htm〉, accessed $19 \mathrm{M}$ ay 2005.

57 'G ender Empowerment M easures', 'G ender Inequality in Education' and 'G ender Inequality in Economic A ctivity' figures in U N D P, Human Development Report 2004, 〈http://hdr.undp.org/ reports/global/2004/pdf/hdr04 HDI.pdf), accessed 25 A pril 2005. F or example, in Egypt, female literacy is 65 per cent of men's literacy; the female economic activity rate is 45 per cent that of men. 
H owever, women are being encouraged to improve their situation in a context of diminishing economic opportunities. M en's anxieties about their sexuality are not only a response to widespread socioeconomic difficulties but also to the apparent challenge to gender relations posed by the allocation of national resources towards improving women's situation. Within this context, the Queen Boat case may be interpreted as an attempt to punish homosexuality in order to 'rescue' Egyptian masculinity from the insecurities experienced as a result of socioeconomic changes and shifting gender roles. Continued masculine domination depends upon the maintenance of heteronormativity - that is, the institutionalisation of heterosexuality as the norm within society. ${ }^{58} \mathrm{H}$ omosexuality challenges the heterosexual order that underpins male domination of women and, therefore, is constructed as a threat to masculinity. As the chief prosecutor in the Queen Boat case stated, 'E gypt has not and will not be a den for the corruption of manhood, and homosexual groups will not establish themselves here'. ${ }^{59}$ The persecution of gay men functions to re-establish heterosexuality as the norm, thereby re-establishing gender hierarchy in a context of shifting gender roles.

\section{The gender and sexuality of national security}

In the Queen Boat case, the punishment of homosexuality was not only represented as a means of securing E gyptian manhood but also as a means of protecting E gyptian national security. A rguments about the threat to national cohesion posed by gay men are almost universal and justify their attempted exclusion from that most masculinist of institutions, the military. ${ }^{60}$ The trial of allegedly gay men not only promoted the view that homosexuality is a potential threat to national security by disrupting the 'proper' homosocial bonding of men.61 $\mathrm{M}$ edia coverage of the Queen Boat case linked the accused men directly to an external security threat. A 'J ewish conspiracy' was seen to be behind the 'cult of the perverts' and the 'ring-leader' or key defendant was reported to have visited Israel. 62

A Ithough Egypt signed a peace accord with I srael in 1979 and, therefore, possesses diplomatic relations with the country, I srael has continued to be consider ed a security threat by many ordinary people as well as members of the Egyptian security and military apparatus. I sraeli actions within the M iddle E ast region, such as the invasion of Lebanon in 1982, the continued occupation of Palestinian territories and Israel's possession of nuclear weapons are seen as illustrative of the dangers posed to regional security and the security of the Egyptian state by the existence of I srael.

The links made between the defendants and the external security threat of I srael contributed to justifying the trial of the men before a State Security Court. These

\footnotetext{
58 Stevi Jackson, 'Interchanges: G ender, Sexuality and H eterosexuality: The Complexity (and Limits) of Heteronormativity,' Feminist Theory, 7:1 (2006), pp. 105-121.

59 Philip Smucker, 'A Clash of Cultures in Egypt', Christian Science Monitor Online, 〈http://www.csmonitor.com/2001/0918/p6sl-wome.htm〉, accessed 6 D ecember 2004.

60 Cynthia Enloe, The Morning After: Sexual Politics at the End of the Cold War (Berkeley, CA: U niversity of California Press, 1993), pp. 71-101.

61 A ndrew Parker, M ary R usso, D oris Sommer and Patricia Y aeger, 'Introduction', in Parker et al. (eds.), Nationalisms and Sexualities, p. 6.

62 Al-Musawwar, 18 M ay 2001, cit. in HRW, In a Time of Torture, p. 40.
} 
courts were originally established under the Emergency Law to deal with cases of national security, in particular the trial of political Islamists charged with acts of terror. Over the years, they have also been used to try political opponents of the regime. Human rights groups have condemned the courts as a violation of international standards of fair trial. Human Rights Watch describes the courts as, 'a parallel court system under direct government control'.63 There is no right of appeal against the final verdict and sentences can only be overturned by the Egyptian president.

In addition to its association with I srael, homosexuality may be constructed as a security threat to the Egyptian nation because it challenges the heterosexual order that is central to nation-state processes. ${ }^{64} \mathrm{M}$ ore specifically, it interrogates the heterosexual ordering of the nation's 'inner sphere' of sexual/gender roles, relations and identities that define national identity and the boundaries of the nation - dividing 'us' from 'them'. 65

Within this context, the public harassment of homosexual men represents an opportunity to regain control of the 'inner domain' of the nation - meaning the sphere of personal and familial relations - by (re)asserting heterosexism as the only socially and politically acceptable means of ordering gender relations and identities. ${ }^{66}$ The fixing of sexual identities as heterosexual reinforces the boundaries of permissible behaviour for both men and women within the national collective, thereby contributing to the construction of national difference.

\section{The gender and sexuality of national identity and culture}

The punishment of homosexuality acts to reproduce E gyptian national identity and culture. The behaviour of the defendants in the Queen Boat case was represented as a threat to Egyptian national identity and culture. The use of the term 'perverts' throughout the case to describe the arrested men, was constructed not only as an act of 'perverting from' the cultural norms of society but also as actively perverting these norms. ${ }^{67}$ In response to A mnesty I nternational's condemnation of the arrest and trial of the 52 men, Rose al-Y oussef argued, 'If they [A mnesty International] consider perversion an expression of personal freedom, we consider it an attack on values and beliefs'. 68

The 'values and beliefs' that politicians and the media sought to defend were concerned with the sexual and moral behaviour of individuals. The media attacked the defendants in the Queen Boat case for practising 'perverted activities', such as holding same-sex marriage ceremonies, taking pornographic photographs and having

\footnotetext{
63 H uman Rights W atch, 'Egypt: H uman R ights Background', October 2001, 〈http://www.hrw.org/ backgrounder/mena/egypt-bck-1001.htm), accessed 28 A pril 2006.

64 Peterson, 'Sexing Political Identities'.

$65 \mathrm{~N}$ ira Y uval-D avis and F loya A nthias (eds.), Woman-Nation-State (L ondon: M acmillan, 1989).

${ }^{66} \mathrm{~F}$ or a discussion of the significance of the 'inner domain' of the nation, see Partha Chatterjee, The Nation and its Fragments (Princeton, N J : Princeton U niversity Press, 1993).

67 F or example, R ose al-Y oussef, 'H ow Could A nyone Believe Them after This R idiculous Statement'.

68 Ibid.
} 
group sex.69 M oreover, these practices were condemned as a form of 'devilworshipping' - thereby portrayed as an attack on religious values.

'R eligion is central to sexual regulation in almost all societies... Indeed, it may well be that the primary social function of religion is to control sexuality and gender in the interests of hegemonic masculinity'. ${ }^{70} \mathrm{D}$ iscriminatory family laws, F emale G enital Cutting and domestic violence, amongst other examples of societal control of (female) sexuality, are all justified by conservatives through recourse to Islam. ${ }^{71}$ Similarly, homosexuality (liwat) is deemed to be a crime within Islam. ${ }^{72}$

$\mathrm{N}$ ot only is Islam central to sexual regulation. Simultaneously, Islam plays an important role in national identification processes within Egypt.73 F or example, the continued existence of discriminatory family laws rooted in I slamic codes is hailed by conservatives as a means of affirming their countries' 'authentic' Islamic roots. ${ }^{74}$ L inked to this, I slam represents a marker of national difference from the West. Consequently, behaviour that is seen to 'pervert from' religious norms is represented as un-Egyptian.

A n essential component in representing homosexuality as a perversion of Egyptian identity and culture rests with its representation as foreign to Egyptian values. Egyptian culture, rooted in Islam, was consistently represented as in opposition to and separate from W estern culture. H ussein D erar, deputy-assistant foreign minister for human rights, said, 'They have their Western culture and we have our Islamic culture'. ${ }^{75}$ (It is ambiguous as to who 'they' are - those living in W estern societies, gay men or international human rights campaigners). According to the chief prosecutor in his opening statement of the Queen Boat case, 'W estern nations accept and tolerate what I slam considers a crime'. ${ }^{76}$

Government officials defended the prosecution of the men on the basis of protecting Egyptian cultural values from W estern decadence. The chief government

69 F or example, Al-Ahrar (newspaper of the Liberal party), 'The A rrest of the M embers of the D evil-W orshippers' Organization: The A ccused Was $\mathrm{H}$ olding a $\mathrm{M}$ arriage Ceremony for Two $\mathrm{M}$ en Each W eek', 14 M ay 2001; Al-Wafd (newspaper of the W afd party), 'The R eturn of the D evil-W orshippers: The A rrest of 55 Suspects in a Shameless Party for the Engagement of Two M en', 13 M ay 2001; Al-Gumhuriyya (state-owned newspaper), 'Satanist Pervert Surprises: They Called Themselves God's Soldiers and Practice Group Sex in Private and Public M eetings Every Thursday at Queen Boat', 15 M ay 2001. All cited in H R W, In a Time of Torture, pp. 22 and 39.

70 Altman, Global Sex, p. 6.

71 H owever, as feminist scholars of women in I slam have argued, I slam was progressive for its time in guaranteeing women's rights to own property and to receive a share of inheritance and in protecting women from less progressive, pre-I slamic practices. The problem is less with the Islamic religion itself than the predominance of patriarchal interpretations of religious texts, which justify gender inequalities on the basis of gender difference. F or example, Leila A hmed, Women and Gender in Islam (L ondon: Y ale U niversity Press, 1992).

72 F or example, A bdelwahab Bouhdiba, Sexuality in Islam (L ondon: R outledge and K egan Paul, 1985), p. 31. Y et, I slamic texts may be reinterpreted in different ways and gay M uslim/M uslim gay men have challenged the hetero-normative/patriarchal interpretations of the Quran, providing alternative readings to open spaces for same-sex, consensual relationships within Islam. F or example, A sifa Siraj, 'On Being Homosexual and M uslim: Conflicts and Challenges', L ahoucine Ouzgane (ed.), Islamic Masculinities (London: Zed Books, 2006), pp. 202-16.

73 N adje A I-A li, Secularism, Gender and the State in the Middle East: The Egyptian Women's Movement (Cambridge: Cambridge U niversity Press, 2000), pp. 40-4.

$74 \mathrm{H}$ ijab, Womanpower.

75 BBC N ews Online, 'E gyptian R ights Group "'Cannot Protect G ays" ', 7 F ebruary 2002, 〈http://news.bbc.co.uk/2/hi/middle_east/1813926.stm〉, accessed 6 D ecember 2004.

76 Philip Smucker, 'A Clash of Cultures in Egypt', Christian Science Monitor Online, 〈http://www.csmonitor.com/2001/0918/p6s1-wome.htm〉, accessed 6 D ecember 2004. 
spokesman, $\mathrm{N}$ abil $\mathrm{O}$ sman argued, 'W hat we did was not a breach of human rights... but actually an interpretation of the norms of our society, the family values of our society ... some of these values in the West are actually in decay'. ${ }^{77} \mathrm{D}$ emonstrating also the class nature of the issue, Egypt's business elite were blamed for promoting homosexuality by adopting 'foreign' lifestyles and turning their back on Egyptian culture. 78

Whilst women's behaviour in both the private and public spheres is often represented as symbolic of a nation's character, 79 the Queen Boat case illustrates the ways in which hegemonic notions of masculinity are inextricably linked to national identity. The representations of homosexuality as a Western cultural norm was predicated on the assumption not only that gay sexuality was 'unEgyptian' but, in addition, was 'un-manly'. Such attitudes are illustrated by the treatment the men received immediately following their arrest. The identification of the men as gay centred upon their appearance as 'un-Egyptian/un-manly'. Different detainees reported that the police officers would ask them to show their underwear. If it was coloured, that was taken to mean that the person was gay. Most male underwear in Egypt is plain white. Coloured underwear is seen as 'Western'.80 Similarly, men with long hair and tattoos are also part of Vice Squad mythologies about identifying gay men. ${ }^{81}$ D etainees wearing the latest Western fashions were deemed effeminate by police officers. One arrested man recalls the events in the police station:

I was the first to be called out. I was well-dressed but he thought my clothes looked 'girlish' though I was just wearing a tight T-shirt top and a jacket and pants [i.e. trousers] with a little flower stitched on them, around the cuff. They all thought I was effeminate, all through this ordeal, so I was singled out for special attention [i.e. particularly brutal abuse]. 82

The implication is that 'real' E gyptian men do not adopt such 'un-Egyptian'/'foreign' ways of dressing. On the other hand, 'masculine'-looking men were not subject to the same brutal and degrading treatment as other detainees. O ne arrested man said, ' $Y$ ou know, I have muscles, I look like a man. The guards respected me'.83 This man also received a shorter prison sentence than other men found guilty (only one year). ${ }^{84}$

The Queen Boat case may be seen as an attempt to reproduce Egyptian identity and re-establish the boundaries of the Egyptian nation by constructing heterosexuality as an essential marker of national difference from the West. The association made between the West and homosexuality, on the one hand, and Egypt and heterosexuality, on the other, demonstrates the way in which sex/sexuality is

77 BBC N ews Online, 'E gypt Crackdown on H omosexuals', 7 M arch 2002, 〈http://news.bbc.co.uk/go/ $\mathrm{pr} / \mathrm{fr} /-/ 1 / \mathrm{hi} /$ programmes/crossing continents/1858469.stm), accessed 6 D ecember 2004.

78 'D r. K halil F adel Tries to R ead between the Lines', Sawt al-Umma (independent newspaper), 24

M ay 2001, cit. in H R W, In a Time of Torture, p. 40.

79 N ira Y uval-D avis, Gender and Nation (L ondon: Sage, 1997); K andiyoti, 'I dentity and its D iscontents', p. 378.

80 BBC N ews O nline, 'E gypt Crackdown on Homosexuals'. One arrested man had thrown away his underwear before arriving at the prison where they would be detained because, ' $\mathrm{H}$ e thought it incriminated him'. H R W, In a Time of Torture, fn. 114.

$81 \mathrm{HRW}$, In a Time of Torture, p. 18.

82 Ibid., p. 32.

83 Ibid., p. 33.

84 Ibid., p. 43. 
inscribed within the power relations between the West and Egypt/M iddle East. ${ }^{85}$ W ithin this context, homosexuality not only represented values that are 'foreign' to Egypt. It was also regarded as representative of Western attempts to undermine Egyptian sovereignty.

\section{Performing national sovereignty/protecting regime authority}

The Queen Boat case associated the existence of homosexuality within Egypt with W estern attempts to intervene in the domestic politics of Egypt, thereby threatening Egyptian sovereignty. A ccording to one commentator, homosexuality constituted 'the globalisation of perversion', thereby linking homosexuality to what is widely regarded as a W estern-controlled process that disregards the needs and interests of countries in the South.86 The performance of the 'Queen Boat case' for an international audience was significant in this respect. I t may be seen as an attempt by Egyptian authorities to publicly defend national sovereignty against Western intervention.

The trial was well attended by the media and representatives of W estern embassies and human rights groups, whilst the families of the defendants were largely excluded from attending the proceedings. Photographers were allowed to take photos and cameramen were allowed to film inside the court. It is as if 'the authorities [had] a curious desire to advertise injustice'. 87 T he defendants attempted to hide their identity with masks torn from white prison clothing. The image of these ghostly figures, sitting in cages for the defendants, became ubiquitous in the media coverage of the event. The trial attracted so much attention that, after the opening session, it was moved to a larger courthouse. ${ }^{88}$

The case sparked a substantial international campaign against the Egyptian authorities. Celebrities in Britain, including E Iton J ohn and G raham N orton, signed a petition to free the arrested men. Rights groups around the world organised demonstrations outside E gyptian embassies. W estern diplomats, government officials and even the $\mathrm{F}$ rench president voiced their concerns about the arrests and treatment of the Queen Boat defendants. ${ }^{89}$ The European Parliament adopted a resolution urging the government to resolve outstanding human rights issues, with explicit reference to the trial of the 52 alleged gay men, as part of the Euro-M editerranean A ssociation A greement. ${ }^{90}$

${ }^{85}$ A more recent event also demonstrates the way in which the military power of the W est is equated with homosexuality. In Egypt, in M ay 2004, there were demonstrations protesting the abuse of prisoners in A bu G hraib prison, Iraq. The protesters blamed the abuse on 'homosexual A merican executioners'. Patrick L etellier, 'E gyptian Protest “'G ay” A buse in Iraq', G ay.com, 18 M ay 2004, 〈http://uk.gay.com/headlines/6271〉, accessed 6 D ecember 2004.

86 'A n Egyptian View', Al-Akhbar newspaper (state-owned), $30 \mathrm{M}$ ay 2001, cit. in HR W, In a Time of Torture, p. 39.

87 L ong, 'The Trials of Culture'.

$88 \mathrm{HRW}$, In a Time of Torture, p. 42.

89 BBC N ews Online, 'E gyptian R ights G roup "Cannot Protect Gays" '; A ge of Consent, ' "Immorality" Trial R econvenes in Egypt'.

90 European Parliament R esolution, 29 N ovember 2001, A ssociation A greement with Egypt (B5-0740/2001); European Parliament resolution on the conclusion of an A ssociation A greement with Egypt. 
In the end, the mounting international criticism no doubt became embarrassing to the government and, in $M$ ay 2002, the president ordered a review of the verdicts of N ovember 2001. Simultaneously, the authorities began to clamp down on domestic reporting of men arrested for homosexuality. On the one hand, one may interpret these actions by the authorities as defensive. $Y$ et, by this time, the Queen Boat case had generated ample proof that E gyptian sovereignty was threatened by the W est in the form of the intervention of various W estern actors in defence of homosexuality.

In this respect, the $\mathrm{Q}$ ueen Boat case operated to demonstrate E gyptian resistance to these interventions, thereby enabling a variety of actors to 'perform' Egyptian sovereignty. In particular, the case demonstrated the regime's authority in its defence of Egyptian sovereignty from foreign influence. The public harassment of gay men and Egyptian media commentaries of the event enabled the widespread diffusion of a discourse defending 'cultural authenticity' in the face of decadent W estern values. This discourse obliged social actors to take sides and provided culturally legitimate grounds for domestic repression, not only against those who digress from heterosexuality but also against those who are associated with defending individual freedoms.

The already embattled Egyptian human rights community became divided over how to respond to the case. ${ }^{91} \mathrm{~A}$ small group of organisations spoke in defence of the men's rights, not only to a fair trial but also to lead their private lives without state interference. ${ }^{92}$ In addition, lawyers from these groups represented the men in court. $M$ eanwhile, some human rights activists avoided commenting or becoming involved in the case. On the other hand, a significant number of organisations rejected not only the idea of the right to express diverse sexual orientations but also refused to represent the Queen Boat defendants on the grounds that homosexuality is not part of Egyptian culture and sexual orientation was not a human right but a Western cultural practice. ${ }^{93}$ One long-standing human rights activist and director of the Egyptian Organisation for $\mathrm{H}$ uman R ights said in an interview:

If we were to uphold this issue, this would be the end of what remains of the concept of human rights in Egypt ... W e let them [the arrested men] down, but I don't have a mandate from the people, and I don't want the W est to set the pace for the human rights movement in Egypt.94

By refusing to defend the men on trial, Egyptian activists could be seen to be 'send[ing] a message to the regime that the rights movement will stand with the state against foreign pressures'. ${ }^{95}$ In other words, the Queen Boat case not only delegitimised homosexuality but also delegitimised public dissent in the name of protecting Egyptian sovereignty, thereby further weakening the freedom of civil society to challenge Egypt's authoritarian regime.

91 Since its emergence at the end of the 1980s, the E gyptian human rights movement has been subject to numerous campaigns to discredit its work by the government and other members of civil society on the grounds that it represents Western interests and values. The Queen Boat arrests happened soon after a pro-democracy activist, Saad Eddin Ibrahim, was found guilty of 'defaming Egypt abroad' (amongst other charges), also in a State Security Court. F or further details, see N icola Pratt, 'E gypt Harasses H uman R ights A ctivists', Middle East Report Press Information Note, 17 A ugust 2000, 〈http://www.merip.org/mero/mero081700.html〉.

92 These groups included the $\mathrm{H}$ isham M ubarak Law Centre, the al- $\mathrm{N}$ adim Centre for the R ehabilitation of Victims of Torture and the Egyptian I nitiative for Personal R ights.

93 R ose al-Y oussef, 'H ow Could A nyone Believe Them after This R idiculous Statement'.

94 BBC N ews Online, 'E gyptian R ights G roup "Cannot Protect G ays" '.

95 Bahgat, 'Explaining Egypt's Targeting of $G$ ays'. 


\section{Conclusion}

This article has drawn attention to the way in which the construction of national security 'threats', such as homosexuality, are inextricably linked to the ways in which gender and sexuality are inscribed within power relations at the interpersonal, national and international levels. Insecurities at the national level, resulting from global political, strategic and economic processes, impact upon gender and sexual relations and identities. Simultaneously, resistance to these insecurities is constructed through attempts to re-establish hetero-normative hierarchies of gender and sexual relations and identities.

The Q ueen Boat case demonstrates not only the significance of gender in national identification processes but also of sexuality as a means of securing gender identities and relations within a context of shifting gender roles. The enforcement of heteronormativity, through the harassment and punishment of homosexuality, operates to fix masculinity and femininity in relation to sexual relations and identities. This occurs within a context in which the government is attempting to liberalise gender roles.

$\mathrm{N}$ orms surrounding sexuality and sexual behaviour are represented as markers of national identity - they define the boundaries of the national collective. Through the Queen Boat case, strictly enforced heterosexuality is characterised as inherent to an 'authentic' national culture - in opposition to less strictly enforced heterosexuality and, hence, more morally corrupt Western culture. Indeed, the case itself was constituted through a set of assumptions about the essential difference between $\mathrm{E}$ gypt and the West with regards to the nature of gender and sexual roles, relations and identities.

$\mathrm{N}$ ational sovereignty is constructed through this process of national differentiation on the basis of 'culture' and 'identity'. Culture, inextricably linked to the private sphere of gender and sexual relations, is seen to represent the 'inner domain' of the nation. The 'outer domain' of geostrategic relations and global political economy is continually subject to foreign intervention and influence (for example, through US political and military dominance and W orld Bank/I M F-imposed economic reforms). Within this context, the 'inner domain' constitutes the only terrain upon which the Egyptian regime may establish state sovereignty and national differentiation may occur. Consequently, the private sphere represents the core of national sovereignty and the terrain upon which national boundaries are drawn and policed.

The construction of monolithic, national cultures and identities constitutes national sovereignty and maintains regime authority within nation-state boundaries. Those that transgress sex/gender norms, also transgress these boundaries, threatening national identity and, consequently, undermining national sovereignty. The use of torture and other humiliating treatment in the detention of the Queen Boat victims illustrates the threat that homosexuality appears to pose to the reproduction of national identity and sovereignty. The fragility of E gyptian sovereignty in relation to other sovereign nation states becomes an implicit justification for the violation of human rights within the domestic arena.

A ttempts by Western governments and international organisations to call Egypt to account for its abuse of human rights on the basis of sexual orientation acts to reaffirm the perceptions of Western interference, as well as contributing to the continual hardening of the so-called 'cultural' differences between the M iddle East 
and the W est. A 'transversal' politics that seeks to open spaces for fluidity, diversity and alterity - both in the W est and in the M iddle East - would contribute to breaking down those differences constructed around notions of immutable and essentialised culture and 'serve to change the ways in which power is negotiated'. 96

Simultaneously, there is a need to continue to address the global political and economic inequalities that contribute towards feelings of disempowerment and frustration amongst people in Egypt and other countries of the South. The assertion of cultural differences by disempowered peoples constitutes a means of asserting autonomy and resisting global inequalities. ${ }^{97} \mathrm{Y}$ et, this contributes to the creation of a politics in which dissent, diversity and difference are either suppressed or criminalised as threatening to national existence. The Queen Boat case in E gypt is an illustration of how such a politics is constructed to the detriment of the human security and human rights of all men and women.

96 Giles and Hyndmann, 'N ew Directions for F eminist R esearch and Politics', p. 314.

$97 \mathrm{M}$ ichael $\mathrm{K}$ immel, 'G lobalization and its $\mathrm{M}$ al(e)contents: The G endered M oral and Political Economy of Terrorism', International Sociology, 18:3 (2003), p. 604. 